\title{
THE IMPORTANCE OF SOCIALIZATION OF POSYANDU TO IMPROVE POSYANDU VISITING, KNOWLEDGE, AND COMMUNITY ATTITUDE TO IMPROVE IMMUNIZATION ACHIEVEMENTS
}

\author{
Welhan Chau', Yohanes Firmansyah² \\ ${ }^{1}$ Universitas Kristen Krida Wacana, Jakarta \\ Email: welhan1244@gmail.com \\ ${ }^{2}$ Dokter Internship RSUD Kalideres, Fakultas Kedokteran, Universitas Tarumanagara, Jakarta \\ Email:yohanesfirmansyah28@gmail.com
}

Masuk: 26-09-2020, revisi: 15-10-2021, diterima untuk diterbitkan: 22-10-2021

\begin{abstract}
ABSTRAK
Data WHO menunjukkan bahwa setiap tahun di dunia terdapat 1,5 juta kematian bayi usia satu minggu dan 1,4 juta bayi lahir mati karena tidak diimunisasi. Angka Kematian Bayi (AKB) merupakan salah satu indikator terpenting yang menentukan derajat kesehatan dan kesejahteraan suatu masyarakat. Penelitian ini dilakukan untuk menilai pentingnya sosialisasi kegiatan posyandu dan peran kader untuk mengajak warga datang ke posyandu karena salah satu faktor yang mendorong kelengkapan imunisasi adalah kehadiran ibu ke posyandu disamping faktor lain yaitu mungkin memainkan peran seperti pengetahuan dan sikap ibu terhadap imunisasi. Desain penelitian ini adalah kuantitatif analitik dengan pendekatan cross sectional yang dilaksanakan di Posyandu Teratai 1 periode Januari 2020. Sampel penelitian ini adalah seluruh ibu yang memiliki bayi berusia 5 tahun yang berada di wilayah cakupan Posyandu Teratai 1. Variabel bebasnya adalah rutin atau tidak rutinnya responden yang hadir selama pelaksanaan Posyandu Teratai 1, pengetahuan dan sikap mereka terhadap imunisasi. Variabel terikat dalam penelitian ini adalah status imunisasi anak - analisis statistik menggunakan uji Chi-square dengan Yates Correction atau uji alternatif Fisher Exact. Hasil Hasil uji statistik menunjukkan bahwa kehadiran rutin di Posyandu (p-value <0,001) berperan penting dalam menyelesaikan imunisasi. Sedangkan pengetahuan dan sikap tidak memiliki peran yang signifikan, tetapi masih memiliki pengaruh khusus terhadap kelengkapan imunisasi (p-values: 0,098 dan 0,240). Salah satu faktor yang berperan dalam peningkatan angka luaran imunisasi di suatu daerah adalah mendorong kehadiran ibu untuk datang ke posyandu secara rutin.
\end{abstract}

Kata kunci: imunisasi; posyandu; kader; pengetahuan; kehadiran

\begin{abstract}
Data from WHO shows that every year in the world, there are 1.5 million infant deaths one week old and 1.4 million stillbirths due to not getting immunized. Infant Mortality Rate (IMR) is one of the most critical indicators that determine the degree of health and welfare of a community. This research was conducted to assess the importance of the socialization of posyandu activities and the role of cadres to invite citizens to come to Posyandu because one of the factors that encourage the completeness of immunization is the presence of mothers to Posyandu in addition to other factors that might play a role such as mothers' knowledge and attitudes towards immunization. The design of this study is a quantitative analytic cross-sectional approach carried out in Posyandu Teratai 1, in the January 2020 period. The sample of this study is all mothers who have 5-year-old babies who are in the coverage area of the Posyandu Teratai 1. The independent variable is the routine or non-routine of the respondents present during the implementation of Posyandu Teratai 1, their knowledge and attitudes towards immunization. The dependent variable in this study is the child's immunization status-the statistical analysis used Chi-square with Yates Correction or Fisher Exact alternative test. Results Statistical test results show that routine attendance at the Posyandu (p-value <0.001) plays a substantial role in completing immunization. While knowledge and attitudes do not represent a significant role, but they still have a particular influence on the completeness of immunization ( $p$ values: 0.098 and 0.240). A factor that has a role in increasing the number of immunization outcomes in an area is to encourage the presence of mothers to come to Posyandu routinely.
\end{abstract}

Keywords: immunization; posyandu;cadre; knowledge; attendances 


\section{BACKGROUND}

Posyandu is a basic health activity organized by, for, and also with the community, with the assistance of health workers, to empower and facilitate the community's access to health services for mothers, infants, and toddlers.

Posyandu already present in the community plays a critical role in advancing maternal and child health development. With the Toddler Posyandu program running smoothly and being carried out once a month in each RW in the Bandungrejosari sub-district, and the coaching carried out alternately by the Puskesmas in each Posyandu that has been spread in each RW, it is extremely beneficial to society, particularly maternal and child health.

Posyandu focuses on five priority programs: family planning, $\mathrm{MCH}$, nutrition, immunization, and diarrhea control. This program has been shown to significantly reduce infant and child mortality rates. Participation of the community in implementing the Toddler Posyandu is critical; without their support, this program will be unable to function properly. Their willingness to come and utilize health services at the posyandu enables them to prevent and detect disturbances and growth retardation in toddlers as early as possible.

We required an active role on the part of the mother in terms of vaccination particularly, when some mothers are be hesitant to bring their children to the Posyandu. Posyandu is not exclusively associated with immunization. Children's weight, height, and head circumference are measured in Posyandu to detect early signs of malnutrition. Unfortunately, a mindset has arisen that the Posyandu is just for weighing and administering immunizations to youngsters.

Apart from the belief about immunizations, moms may refrain from bringing their children to the Posyandu. They assume that their child is healthy, hence does not require visit to the Posyandu. Since 2015, a program called Combined Posyandu has existed, specifically Posyandu that is integrated with PAUD and BKB (Bina Keluarga Toddler).

Immunization is an attempt to actively induce or increase a person's immunity to a disease by administering a vaccine so that if one day they are exposed to the virus, they will not get sick or only experience mild illness. (Penyelenggaraan imunisasi. Permenkes No.42/2013, 2013) In general, the purpose of immunization is to reduce morbidity, disability and deaths from diseases that can be prevented by immunization, namely tuberculosis, diphtheria, pertussis, Haemophilus influenza type B, measles, polio, tetanus and hepatitis B.(Direktorat Jenderal Pengendalian Penyakit dan Penyehatan Lingkungan, 2013)

This immunization activity has been carried out routinely throughout Indonesia since 1956 . Then in 1977, WHO began the implementation of the immunization program as an official global effort and was called an Expanded Program on Immunization (EPI) known in Indonesia as the Immunization Development Program (PPI). In 1990 Indonesia nationally achieved Universal Child Immunization (UCI) status, which included a minimum of $80 \%$ (Measles) before a child was one year old, and coverage for DPT-3 was at least 90\%. (Bennett, 2016; World Health Organization, 2014)

Data from WHO shows that every year in the world, there are 1.5 million infant deaths one week old and 1.4 million stillbirths due to not getting immunized. Infant Mortality Rate (IMR) is one of the most critical indicators that determine the degree of health and welfare of a community. Based on WHO data show that the Infant Mortality Rate (IMR) in the world in 2017 was 29 per 
1000 live births. Data from the Current World Infant Mortality Rate shows that the Infant Mortality Rate (IMR) in the world in 2015 was 32 per 1000 live births. (Bennett, 2016; World Health Organization, 2014)

The infant mortality rate in Indonesia is still relatively high. Based on the 2012 Indonesia Demographic Health Survey (IDHS), 32 IMR per 1,000 live births, down slightly compared to 2007, which was 34 per 1,000 live births. (Kementerian Kesehatan Republik Indonesia, 2014; Kementrian Kesehatan, 2014) This IMR is still far from the target set in the fourth Millennium Development Goals (MDGs), namely reducing infant mortality. In the MDGs, the IMR target to be achieved in 2015 is 23 per 1000 live births. Life expectancy for children aged one year and over is primarily determined by health services when the baby is mainly through an immunization program. So the Ministry of Health recommends that all children before the age of one year have received complete and regular immunizations so that the effectiveness of immunization can reach $85-90 \%$, to reduce the Infant Mortality Rate (IMR). (Kementerian Kesehatan Republik Indonesia, 2014; Rencana strategis Kementerian Kesehatan tahun 20152019., 2015; Kementrian Kesehatan, 2014)

UCI (Universal Child Immunization) is the achievement of complete primary immunization in infants (children under one year of age). (Rencana strategis Kementerian Kesehatan tahun 20152019., 2015) This will certainly affect the IMR. In 2010, the government launched the Universal Child Immunization National Immunization Acceleration Program 2010-2014 (Direktorat Surveilens, Imunisasi, Karantina dan Kesehatan Matra Direktorat, 2015). In this program, the government targets the village or district coverage to reach UCI to be $100 \%$ in 2014 . However, in 2014 the UCI target only got $81.82 \%$, so the government set a new goal of UCI village or district coverage by $84 \%$ in 2015 and $92 \%$ in 2019. (Direktorat Surveilens, Imunisasi, Karantina dan Kesehatan Matra Direktorat, 2015; Kementerian Kesehatan Republik Indonesia, 2014; Rencana strategis Kementerian Kesehatan tahun 2015-2019., 2015; Kementrian Kesehatan, 2014).

The Ministry of Health in 2008 recommended that all children before the age of one year have received necessary and complete immunizations so they can have good health while breaking the chain of transmission. (Rencana strategis Kementerian Kesehatan tahun 2015-2019., 2015) Regularly regulating the schedule and the number of immunization frequencies. Complete primary immunization in infants includes one dose of hepatitis B-0, one dose of BCG, three doses of DPT, four doses of polio, three doses of hepatitis B, and one dose of measles. (Rencana strategis Kementerian Kesehatan tahun 2015-2019., 2015) If immunization is carried out correctly and thoroughly, then the effectiveness of immunization can reach 85-90\%. According to the 2013 Basic Health Research (Riskesdas), basic immunization coverage is Hep B-0 (79.1\%), BCG (87.6\%), measles (82.1\%), polio-4 (77\%), and DPT-HB-3 (75.5\%). (Kementerian Kesehatan Republik Indonesia, 2014; Kementrian Kesehatan, 2014)

Posyandu, as one of the health service sites in its activities, involves community participation carried out by health cadres who have received education and training from Puskesmas on essential health services. The purpose of the posyandu program is to increase community participation in developing health activities and other activities that support the improvement of the ability to live a healthy life (Effendi, 1998). 
Considering that immunization is one of the activities in a posyandu, it is clear that the completeness of immunization in a particular area is also determined by the implementation of the posyandu program in that region. Immunization in infants is said to be complete if the toddler has received the immunizations required by the government and the association of Indonesian paediatricians including BCG, DPT, polio, measles and hepatitis B. (Direktorat Surveilens, Imunisasi, Karantina dan Kesehatan Matra Direktorat, 2015; Kementerian Kesehatan Republik Indonesia, 2014; Rencana strategis Kementerian Kesehatan tahun 2015-2019., 2015; Kementrian Kesehatan, 2014)

Some of the obstacles faced by posyandu in implementing the program include lack of facilities, lack of trained cadres, and lack of community awareness of the importance of posyandu. Besides that, the unavailability of buildings for posyandu is also an obstacle for posyandu activities. These constraints cause the posyandu to function less, which results in a lack of community interest in using the posyandu. Further consequences are many things that can be useful for mothers to understand how to care for children from the womb properly, then increase the safety of mothers during childbirth quickly and affordably, becoming unworkable (Soedirdja, 2001)

This research was conducted to determine the importance of the socialization of posyandu activities and the role of cadres to invite citizens to come to Posyandu because one of the factors that encourage the completeness of immunization is the presence of mothers to Posyandu in addition to other factors that might play a role such as mothers' knowledge and attitudes towards immunization

\section{METHOD}

The design of this study is a quantitative analytic comparative cross-sectional approach carried out in Posyandu Teratai 1, RW 008, Kedaung Kaliangke Sub-District, Cengkareng District, West Jakarta in the January 2020 period. The population in this study was all mothers who had babies under five years old. The sample of this study is all mothers who have 5-year-old babies who are in the coverage area of the Posyandu Teratai 1. The inclusion criteria in this study are domiciled in the coverage area of Posyandu Teratai 1 and have a KIA book. Exclusion criteria in this study were in the form of a KIA (Kesehatan Ibu dan Anak) book or immunization records that were lost, they refused to be interviewed, or there were no competent families at the time of the interview. The sample allocation in this study was divided into two without giving treatment. The first sample allocation or group is a group of respondents who regularly come and attend Posyandu Teratai 1.

In contrast, the second sample allocation or group is a group of respondents who are not routine or have never been to Posyandu Teratai 1 but are domiciled in the coverage area of the Posyandu Teratai 1. The sample uses simple random sampling with a minimum sample size in 1 group of 30 respondents. All respondents were asked to fill out a questionnaire in which primary demographic data, questionnaires were used to measure knowledge and attitudes, and show the KIA handbook or immunization records they have. The independent variable in this study is the routine or non-routine of the respondents present during the implementation of Posyandu Teratai 1 , their knowledge and attitudes towards immunization. The dependent variable in this study is whether or not the child's immunization status is complete. The statistical analysis used in this study is the Chi-square with Yates Correction statistical test with Fisher Exact alternative test for nominal-scale data by also measuring the magnitude of risk using Prevalence Risk (PR) between variables. The difference between the two groups is concluded if the p-value $<0.05$ and the 
absence of differences between the two groups is concluded if the $p$-value $\geq 0.05$. This research is the final project of Doctor Internship and has obtained permission from the Health Center for its implementation. The research letter is stated based on the assignment letter Number: DG.02.04 / 2.1 / 5607/2019

\section{RESULTS}

The data collection process was carried out in January 2020 by surveying through a questionnaire that we gave to mothers of routine children and not routinely to Posyandu. In this activity followed by 62 respondents with several 31 respondents who regularly go to the posyandu and 31 respondents who do not routinely go to the posyandu. Mother's work is generally as many as 47 housewives (75.8\%). Last Education Mothers are typically senior high school as many as $41(66.1 \%)$, and most children are one child as many as $28(45.2 \%)$ followed by two children as many as $24(38.7 \%)$. (table 1$)$.

Table 1. Demographic Distribution for Posyandu Teratai 1

\begin{tabular}{|c|c|c|c|}
\hline Parametric & $\mathbf{N}(\%)$ & Mean (SD) & Med (Min-Max) \\
\hline Mother's age & & $31,51(5,99)$ & $29,5(23-25)$ \\
\hline Age of child & & $25,61(13,54)$ & $24(4-56)$ \\
\hline \multicolumn{4}{|l|}{ History of childhood illness } \\
\hline - Yes & $6(10 \%)$ & & \\
\hline - $\mathrm{No}$ & $56(90 \%)$ & & \\
\hline \multicolumn{4}{|l|}{ Mother's job } \\
\hline - Labor & $1(1,6 \%)$ & & \\
\hline - $\quad$ Lecturer & $1(1,6 \%)$ & & \\
\hline - Housewife & $47(75,8 \%)$ & & \\
\hline - Sell Online & $1(1,6 \%)$ & & \\
\hline - Shop employees & $4(6,5 \%)$ & & \\
\hline - General employees & $5(8,1 \%)$ & & \\
\hline - Civil Servants & $1(1,6 \%)$ & & \\
\hline - Entrepreneur & $2(3,2 \%)$ & & \\
\hline \multicolumn{4}{|l|}{ Last education } \\
\hline - Primary school & $4(6,5 \%)$ & & \\
\hline - Junior High School & $13(21 \%)$ & & \\
\hline - Senior High School & $41(66,1 \%)$ & & \\
\hline - College & $4(6,5 \%)$ & & \\
\hline \multicolumn{4}{|l|}{ Number of children } \\
\hline - 1 & $28(45,2 \%)$ & & \\
\hline - 2 & $24(38,7 \%)$ & & \\
\hline - 3 & $6(9,7 \%)$ & & \\
\hline - 4 & $3(4,8 \%)$ & & \\
\hline - 5 & $1(1,6 \%)$ & & \\
\hline \multicolumn{4}{|l|}{ Knowledge } \\
\hline - Lack & $21(33,9 \%)$ & & \\
\hline - Good & $41(66,1 \%)$ & & \\
\hline Attitudes & & & \\
\hline
\end{tabular}




\begin{tabular}{|c|c|c|c|}
\hline Parametric & $\mathbf{N}(\%)$ & Mean (SD) & Med (Min-Max) \\
\hline - $\quad$ Lack & $54(87,1 \%)$ & & \\
\hline - Good & $8(12,9 \%)$ & & \\
\hline Routine comes to Posyandu & & & \\
\hline - Not a routine & $31(50 \%)$ & & \\
\hline - Routine & $31(50 \%)$ & & \\
\hline Immunization Status & & & \\
\hline - Incomplete & $22(35,5 \%)$ & & \\
\hline - Complete & $40(64,5 \%)$ & & \\
\hline
\end{tabular}

Based on the results of the Pearson Chi-Square with Yates Correction statistical test to assess the relationship between attendance at the Posyandu and maternal knowledge regarding an immunization to the completeness of immunization, the results show that there is a significant relationship between not routinely coming to Posyandu with incomplete immunization status with the amount of risk (prevalence risk / PR) amounted to 2.636 times higher. On the other hand, it is also known that a lack of knowledge about immunization has a risk magnitude of 1.443 times more likely for incomplete immunization status. However, it is not statistically significant (p-value> 0.05). Still, the lower value at $95 \% \mathrm{CI}$ reaches above one, which indicates knowledge plays an essential role in the achievement of completeness of immunization.

Based on the results of the Fisher Exact statistical test, it was found that the relationship was insignificant between attitudes lacking with the achievement of the incompleteness of immunization (p-value> 0.05). Still, in terms of risk (prevalence risk / PR), it was known that groups with less attitude had a 1,432-possibility chance of having incomplete status immunization. On the other hand, the lower value at $95 \%$ CI reaches a number above 1, which indicates that attitude plays a vital role in achieving complete immunization.

Table 2. Relationship between Attendance, Knowledge, and Attitudes with Immunization Achievements

\begin{tabular}{|c|c|c|c|c|c|c|c|c|c|}
\hline \multirow{3}{*}{\multicolumn{2}{|c|}{ Parametric }} & \multicolumn{4}{|c|}{ Immunization Status } & \multirow[t]{3}{*}{$\mathbf{P R}$} & \multirow{2}{*}{\multicolumn{2}{|c|}{$\begin{array}{c}\text { Confidence } \\
\text { Interval 95\% }\end{array}$}} & \multirow[t]{3}{*}{$p$} \\
\hline & & \multicolumn{2}{|c|}{ Incomplete } & \multicolumn{2}{|c|}{ Complete } & & & & \\
\hline & & $\mathbf{N}$ & $\%$ & $\mathbf{N}$ & $\%$ & & Min & Maks & \\
\hline \multirow{4}{*}{$\begin{array}{l}\text { Routine comes } \\
\text { to Posyandu } \\
\text { Knowledge }\end{array}$} & Not Routine & 29 & 93,3 & 2 & 6,5 & 2,636 & 1,626 & 4,276 & $<0,001$ \\
\hline & Routine & 11 & 35,5 & 20 & 64,5 & & & & \\
\hline & Lack & 17 & 81 & 4 & 19 & 1,443 & 1,026 & 2,030 & 0,098 \\
\hline & Good & 23 & 56,1 & 18 & 43,9 & & & & \\
\hline \multirow{2}{*}{ Attitude } & Lack & 7 & 87,5 & 1 & 12,5 & 1,432 & 1,022 & 2,006 & 0,240 \\
\hline & Good & 33 & 61,1 & 21 & 38,8 & & & & \\
\hline
\end{tabular}

\section{DISCUSSION}

There are so many factors that influence the completeness of immunization for children under five. One of Rahmi's researches stated that several factors related to the determinants of completeness of complete basic immunization in infants in achieving Universal Child Immunization (UCI) in the work area of the Meurah Health Center were the role of health workers $(p$-value $=0.004)$, sources of information $(p$-value $=0.006)$, the issue of illegitimate immunization ( $p$-value $=0.015)$, and vaccine side effects $(p$-value $=0.001)$. On the other hand, other factors that are less influential in achieving basic immunization in infants are the role of religious leaders $(0.683)$, the role of community leaders $(0.330)$, and the activeness of posyandu 
cadres (0.289). (Rahmi, 2019) This indicates that the participation of health workers and information on posyandu plays a crucial role in the achievement of basic immunization in infants.

The results of the binary logistic regression test from Prihanti and colleagues showed that there were four variables that had a significant effect on the completeness of basic immunization, namely age $(\mathrm{p}=0.029 ; \mathrm{CI}=0.012-0.955 ; \mathrm{OR}=0.106)$, occupation $(\mathrm{p}=0.026 ; \mathrm{CI}=1,300-9,539$; $\mathrm{OR}=3,521)$, Knowledge $(\mathrm{p}=0.019 ; \mathrm{CI}=0.054-0.928 ; \mathrm{OR}=0.224)$, and toddler attendance $(\mathrm{p}$ $=0.00)$ Based on the adjusted $\mathrm{R}$ square value of $0.354(35.4 \%)$. The most dominant factor influencing the completeness of immunization is indicated by the highest p-value, namely the employment factor $(\mathrm{p}=1.590)$. While the insignificant factors include education $(\mathrm{p}=0.309)$, income $(p=0.378)$, attitude $(p=0.057)$, and the role of officers $(p>0.05)$.(Prihanti et al., 2016)

The results of the bivariate analysis from Triana Research obtained knowledge (0.007), attitude (0.014), motivation (0.001), and information (0.04) have a significant role in immunization outcomes. In contrast, education (0.34), employment (0.66), health services (0.47), and barriers (0.43) do not have a significant relationship with immunization. (Triana, 2017) The importance of knowledge and attitude in immunization is the main thing in immunization achievement. (Dillyana \& Nurmala, 2019; Erlita \& Putri, 2018; Istawati, 2019; Wahidin, 2018)

According to the three studies mentioned previously, the findings are consistent with the current research. It was discovered that the role of cadres as the spearhead of Posyandu activities to improve immunization outcomes is significant. Cadres play a role in promoting the timing of Posyandu activities as well as providing relevant information on the usefulness of immunization.

Research from Susanti stated that there was a significant relationship between the role of Posyandu cadres and basic immunization completeness ( $p$-value <0.001). This study also revealed that there was a strong correlation between the role of cadres and immunization completeness with a correlation value of 0.658. (Susanti, 2011) The Septianingtyas research also reinforces other research that the role of cadres in increasing immunization achievement rates and disseminating information to the public is significant. (p-value: 0.013) (Septianingtyas et al., 2018)

Descriptive research from Ervina revealed differences in the status of immunization completeness between groups with Posyandu that were implemented and Posyandu that were not implemented. The results of this study found that the percentage of the implementation of the posyandu program based on the completeness of the immunization status, which had an accomplished state, was $62.8 \%$, and that was not implemented was $37.2 \%$. Percentage of completeness of immunization status, which has a proficient group is $65.4 \%$, and that is not implemented is $34.6 \%$. (Ervina, 2013)

Completeness of primary immunization in infants as an effort to prevent diseases that can be prevented by immunization is influenced by family traditions that are accustomed to giving injections to infants or toddlers having a baby chance, or their toddlers will get complete immunizations and families supporting the immunization of infants or toddlers have the opportunity to get complete immunizations. Research by Rahwati and colleagues stated that the completeness of immunization status was influenced by tradition $(\mathrm{p}=0.015)$ and family support 
$(\mathrm{p}=0.001)$. Rahwati and friends suggest that there is a need for an approach to health promotion to the community to change the tradition of not being accustomed to giving immunizations to being supportive of providing immunizations and giving understanding to family decisionmakers that immunization benefits the baby or toddler. (Rahmawati \& Umbul, 2014)

This is because if mothers are aware of the posyandu's benefits and services, as well as the advantages of bringing toddlers to the posyandu and its significance. When a mother uses KMS as a tool for recording and observing her child's health development, which is simple for her to do, the mother can assess and take action to improve her child's health. This is consistent with the theory that someone's knowledge is the foundation for action, as one's ability to do something is contingent on the knowledge he possesses. On the basis of her knowledge of posyandu, the objectives, and benefits realized through posyandu, mother is able to attend each posyandu implementation. According to several studies conducted in the same field, a significant relationship existed between mother's knowledge and toddler visits to the posyandu. This is also attributable to the active participation of posyandu cadres.

\section{CONCLUSION}

A factor that has a role in increasing the number of immunization outcomes in an area is to encourage the presence of mothers to come to Posyandu routinely. In this case, the role of cadres in the posyandu schedule socialization, increasing knowledge and improving maternal attitudes towards immunization is significant because cadres are the most recognized and trusted members of the community and the surrounding environment

\section{Acknowledgement}

We extend our heartfelt thanks to all parties who participated in the completion of this study. Thanks to Dr Wisnu Eko Prasetyo as the Head of the Cengkareng District Health Center, who has given research permission and Dr Desi Natalia Giniting as Head of the Kedaung Kaliangke Village Health Center and all Kedaung Kaliangke Health Center employees.

\section{REFERENCE}

Bennett, S. (2016). who | global health observatory (gho) data. In Who.

Dillyana, T. A., \& Nurmala, I. (2019). Correlation of knowledge, attitude and mother perception with basic immunization status in wonokusumo. Jurnal Promkes, 7(1), 68-78. https://doi.org/10.20473/jpk.V7.I1.2019.68

Direktorat Jenderal Pengendalian Penyakit dan Penyehatan Lingkungan. (2013). Modul pelatihan imuniasi bagi petugas puskesmas.

Direktorat Surveilens, Imunisasi, Karantina dan Kesehatan Matra Direktorat, D. J. P. \& P. K. R. (2015). Program immunisasi ibu hamil, bayi dan batita di Indonesia. 23-25.

Effendi. (1998). Panduan kader dalam kegitan posyandu (1st ed.). PT Rineka Cipta.

Erlita, C., \& Putri, E. (2018). Hubungan Pengetahuan dengan sikap dalam pemberian imunisasi dasar lengkap pada ibu yang memiliki bayi 0-9 bulan. Jurnal Kebidanan, 8(1), 125-133. https://doi.org/10.33486/jk.v8i1.27

Ervina, L. (2013). Gambaran pelaksanaan program posyandu dan status imunisasi balita di wilayah kerja puskesmas suak ribee kecamatan johan pahlawan kabupaten aceh barAT [Universitas Teuku Umar]. http://repository.utu.ac.id/641/1/BAB I_V.pdf 
Istawati, R. (2019). Faktor yang berhubungan dengan kelengkapan imunisasi dasar di puskesmas rawat inap simpang tiga. 8 .

Kementerian Kesehatan Republik Indonesia. (2014). Situasi dan analisa imunisasi (pp. 1-8).

Rencana strategis Kementerian Kesehatan tahun 2015-2019., Pub. L. No. Kepmenkes RI No.HK.02.02/MENKES/52/2015 (2015).

Kementrian Kesehatan. (2014). Profil kesehatan indonesia tahun 2013. In Jakarta: Kementerian Kesehatan RI. https://doi.org/351.770.212 Ind P

Penyelenggaraan imunisasi. Permenkes No.42/2013, Pub. L. No. Permenkes No.42/2013 (2013).

Prihanti, G. S., Rahayu, M. P., \& Abdullah, M. N. (2016). Faktor - faktor yang mempengaruhi status kelengkapan imunisasi dasar diwilayah kerja puskesmas x kota kediri. Saintika Medika, 12(2), 120. https://doi.org/10.22219/sm.v12i2.5276

Rahmawati, A. I., \& Umbul, C. (2014). Faktor yang mempengaruhi kelengkapan imunisasi dasar di kelurahan krembangan utara. Jurnal Berkala Epidemiologi, 2, 59-70.

Rahmi, H. (2019). Analisis beberapa faktor yang berhubungan dengan kelengkapan imunisasi dasar lengkap pada bayi dalam pencapaian universal child immunization (uci) di wilayah kerja puskesmas meurah dua kabupaten pidie jaya tahun 2019 [Hasil Telusur Hasil web Universitas Muhammadiyah Aceh - UNMUHA]. In Unmuha Repository. http://repository.unmuha.ac.id:8080/xmlui/handle/123456789/205

Septianingtyas, W., Soesetijo, F., \& Widi, R. (2018). Pengaruh dukungan kader dalam imunisasi dasar lengkap di wilayah kerja puskesmas jelbuk dan klatakan, kabupaten jember. Multidisciplinary Journal Published, 1(1), 21-24. https://doi.org/https://doi.org/10.19184/multijournal.v1i1.8593

Soedirdja. (2001). Pedoman umum revitalisasi posyandu (departemen dalam negeri dan otonomi daerah (ed.); 1st ed.). Departemen dalam Negeri dan Otonomi Daerah.

Susanti, L. W. (2011). Hubungan peran kader posyandu dengan kelengkapan imunisasi dasar di desa kwarasan, sukoharjo. [Universitas Sebelas Maret]. https://digilib.uns.ac.id/dokumen/detail/24006/Hubungan-Peran-Kader-Posyandu-DenganKelengkapan-Imunisasi-dasar-di-desa-kwarasan-sukoharjo

Triana, v. (2017). faktor yang berhubungan dengan pemberian imunisasi dasar lengkap pada bayi tahun 2015. Jurnal Kesehatan Masyarakat Andalas, 10(2), 123. https://doi.org/10.24893/jkma.v10i2.196

Wahidin, W. (2018). Analisis faktor-faktor yang mempengaruhi tingkat kunjungan ibu dengan anak balita ke posyandu dalam kegiatan penimbangan di wilayah kerja puskesmas suradita kecamatan cisauk kabupaten tangerang. Jurnal JKFT, 2(2), 29. https://doi.org/10.31000/jkft.v2i1.693

World Health Organization. (2014). Global health observatory (gho): the data repository. World Health Organization. 
THE IMPORTANCE OF SOCIALIZATION OF POSYANDU TO IMPROVE

POSYANDU VISITING, KNOWLEDGE, AND COMMUNITY ATTITUDE

TO IMPROVE IMMUNIZATION ACHIEVEMENTS

(halaman ini sengaja dikosongkan) 